\title{
Production of Xylitol from Oil Palm Empty Friuts Bunch: A Case Study on Bioefinery Concept
}

\author{
MTAP Kresnowati ${ }^{1}$, Efri Mardawati ${ }^{1,2} \&$ Tjandra Setiadi $^{1}$ \\ ${ }^{1}$ Department of Chemical Engineering, Faculty of Industrial Technology, Institut Teknologi Bandung, Indonesia \\ ${ }^{2}$ Department of Agroindustrial Technology, Universitas Padjadjaran, Indonesia \\ Correspondence: MTAP Kresnowati, Department of Chemical Engineering, Faculty of Industrial Technology, \\ Institut Teknologi Bandung, Indonesia. E-mail: tjandra@che.itb.ac.id
}

Received: May 4, 2015

Accepted: June 5, 2015

Online Published: June 30, 2015

doi:10.5539/mas.v9n7p206

URL: http://dx.doi.org/10.5539/mas.v9n7p206

\begin{abstract}
The concept of biorefinery offers the utilization of biomass, in particular agricultural waste, to be converted into energy, chemicals, materials, and food. In 2013 Indonesia produced about 27.4 thousand tons of crude palm oil (CPO) which corresponds to approximately 30 thousand tons of oil palm empty fruit bunches (EFB), the biomass waste from palm oil industries. The huge availability of EFB in Indonesia may serve as a good starting point to implement the concept of biorefinery. EFB mainly comprises of cellulose, hemicellulose and lignin. The cellulosic components of EFB have been thoroughly studied, i.e. for the production of bioethanol. The hemicellulosic component of EFB, which is a polymeric substance that comprises mainly of xylose, has been barely explored. This paper reviewed the potential utilization of hemicellulosic component of EFB to be converted to xylitol, the 5-carbon-sugar-alcohol which is low calorie, low Glycemic Index, and anti-cariogenic. The pretreatment and hydrolysis of EFB and the following fermentation of EFB hydrolysate to xylitol will be discussed further.
\end{abstract}

Keywords: enzymatic hydrolysis, fermentation, hemicellulose and xylitol

\section{Introduction}

Indonesia produced 17.5 million tons crude palm oil (CPO) in 2008 . This tonnage increased by $50 \%$ to 26 million tons in 2012 and made Indonesia the biggest CPO producer in the world. Along with the production of $\mathrm{CPO}$, the industry also produces palm kernel and solid wastes, such as empty fruit bunches (EFB), fiber, and shell, as well as liquid wastes, palm oil mill effluent (POME). The processing of 1 ton of oil palm fresh fruit bunch (FFB) would give 0.22 tons of EFB, 0.12 tons of fiber, and 0.05 tons of shell, and up to $2.5-3.75$ tons of POME (Rupani et al., 2010; Visvanathan et al., 2009). Using this data, besides producing CPO, in 2012, Indonesia produced 28.6 million tons of EFB, 15.6 million tons of fiber, 6.5 million tons of shell, and $325-487$ million tons of POME. This massive amount of waste could serve as potential raw materials for other industries.

In the concept of biorefinery, biomass feedstock is converted into a spectrum of valuable products. It is analogue to the concept of petroleum refinery where the petroleum is converted into a spectrum of energy and chemicals. This concept has been applied and commercial plants are being developed. Abengoa is developing a commercial plant that applies biochemical processes to convert stover, switch grass, and woody biomass mainly to bioethanol in Kansas, POET is developing a commercial plant in Iowa that applies biochemical processes to convert corn cobs mainly to bioethanol (http://wwwl.eere.energy.gov/bioenergy/integrated_biorefineries.html). Indeed several processes have been suggested for the utilization of the biomass waste from palm oil industries. The utilization of EFB, for example, was proposed for syngas via gasification (Susanto et al. 1997), for bio-oil (Chang et al., 2014), for compost of biofertilizer (Zainudin et al., 2014), pulp (Singh et al., 2014), polymer composite (Mahjoub et al., 2013), polyhydroxyalkanoate (Hassan et al., 2013), biogas (Embrandiri et al., 2012), or bioethanol (Sudiyani et al., 2013).

Considering that EFB is a lignocelullosic material, EFB can be potentially used as the raw material for the production of xylitol (Figure 1), a 5-carbon atom sugar alcohol that has a similar level of sweetness to sucrose, but lower calorie. It is a natural sweetener that can be found in fruits and vegetable, albeit in small quantity. The glycemic index of xylitol is low and thus can be safely used by diabetic people. In addition, xylitol has a strongly 
negative heat of solution thus can give a 'cooling sensation'. Xylitol is widely used in food and pharmaceutical industries. In 2007, the world market of xylitol reached $\$ 340$ million at a price of \$ 4-5 per kg (Toyoda et al., 2009). Internet survey shows that China is the main xylitol producer in the world.<smiles>OC[C@@H](O)C(O)[C@H](O)CO</smiles>

Figure 1. Structural Formula of Xylitol

Steps involved in the production of xylitol from EFB are the conversion of its hemicellulose to xylose via pretreatment and hydrolysis, and reduction of xylose to xylitol. This article highlights the implementation of biorefinery concept for the conversion of oil palm EFB to xylitol. Overall, enzymatic hydrolysis of EFB followed by yeast fermentation of hydrolysate is proposed for the production of xylitol from EFB (Figure 2). The aspects involved in the xylitol production, covering the characterization of EFB, pretreatment, enzymatic hydrolysis, fermentation, downstream processing, as well as the economic aspects will be discussed further.

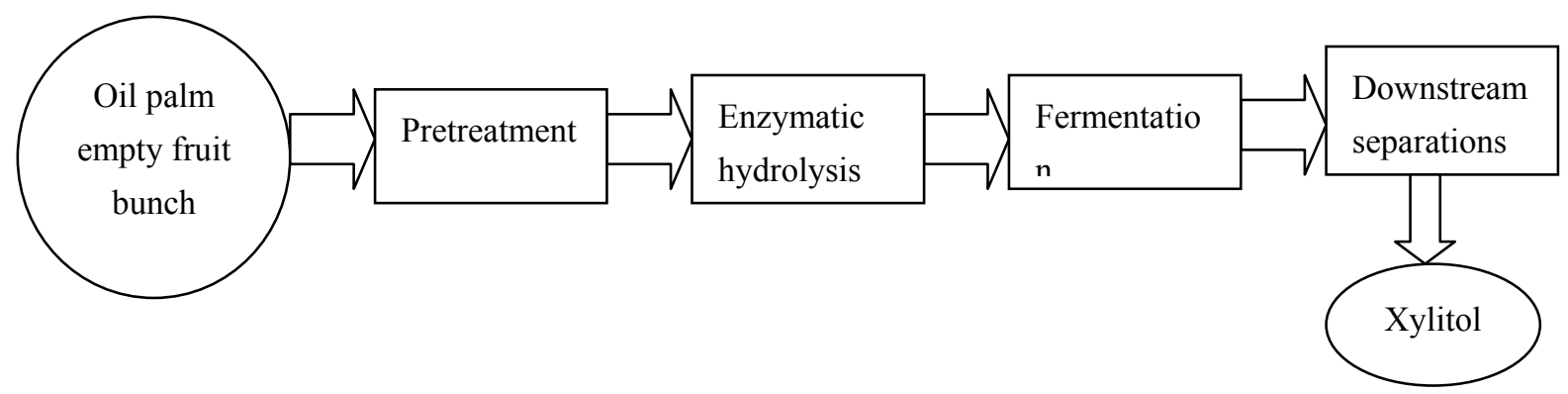

Figure 2. Microbial Production of Xylitol from EFB

\section{Oil Palm Empty Fruit Bunch}

Oil Palm Empty Fruit Bunch (EFB) is the main biomass waste of the palm oil milling process According to (Visvanathan et al., 2009), 0.22 tons of EFB is produced from every ton of FFB or 1.1 tons of EFB will be produced for every ton of CPO. EFB is lignocellulosic material, which composition depends on the genetics of the oil palm as well as the environmental condition where the oil palm tree is grown. Despite some variation in the composition, Table 1 shows that cellulose, lignin, and hemicellulose are the main components of EFB. Cellulose is the homopolymer of glucose, linked by $\beta 1 \rightarrow 4$ glycosidic bond. The strong hydrogen interaction between glucose monomer makes cellulose has a high tensile strength and strong crystalline structure. Lignin is a complex biopolymer comprises of aromatics compounds. In the lignocellulosic material, lignin links cellulose and hemicellulose, it also provides the structural support for the biomass. Hemicellulose is a heteropolymer comprises mainly of 5-carbon atom sugars, such as xylose and arabinose. Component analysis of EFB showed in (Mardawati et al., 2013; Octavia, 2013) showed that xylose composes $19.2-19.6 \%$ of EFB, whereas arabinose, mannose and galactose are detected at lower level, successively at $1.9 \%, 1.4 \%$, and $1.2 \%$ (on dry basis). These show that the hemicellulose of EFB is mainly composed of xylose, and further suggests that EFB has the potential to be used as the raw material for xylitol production.

Table 1. Composition of Oil Palm Empty Fruit Bunch (dry basis)

\begin{tabular}{cccl}
\hline & Composition & & \multicolumn{1}{c}{ References } \\
\hline Cellulose & Hemicellulose & Lignin & \\
\hline $42.85 \%$ & $11.70 \%$ & $24.01 \%$ & Rahman et al., 2007 \\
$33.25 \%$ & $23.24 \%$ & $25.83 \%$ & Sudiyani et al., 2013 \\
$33.25 \%$ & $23.24 \%$ & $25.83 \%$ & Millati et al., 2011 \\
$43-43.47 \%$ & $22.93-23.67 \%$ & $21.28-22.10 \%$ & Mardawati et al., 2014 \\
\hline
\end{tabular}




\section{Pretreatment}

Lignocellulosic material is such a complex polymeric material that its physicochemical structure and composition may hinder the enzymatic digestibility of its components. The pretreatment is performed to increase the access of enzyme to the material (Mosier et al., 2005). The pretreatment process can be either physical, chemical, or physicochemical processes. Examples of physical pretreatment process are milling, thermal, or radiation. In the chemical pretreatment process, chemical substances such as dilute alkali or dilute acid are added to degrade the structure of lignocellulosic material. Physicochemical process is a combination of both involving the addition of chemical substances and extreme physical process, such as steam explosion. Different pretreatment process has been evaluated in utilizing EFB for bioethanol production, for example the research studied the dilute alkaline steam explosion (Choi et al., 2013), other research studied the combine use of white rot fungi and phosphoric acid (Isroi et al., 2012), and the use of bisulphite for EFB pretreatment (Tan et al., 2012). It should be noted that the main compound needed for xylitol production, the hemicellulose, is easier to degrade than cellulose or lignin. Therefore the condition for pretreatment should be designed as such that hemicellulose is not over-degraded or lost during the pretreatment. Kim et al. (2012) reported that dilute acid pretreatment of EFB will remove $90 \%$ of the hemicellulose and the degradation kinetics of hemicellulose under acid pretreatment. Imman et al. (2013) reported that EFB pretreatment with compressed liquid hot water at $200^{\circ} \mathrm{C}$ for 5-20 minutes led to high level of hemicellulose solubilising. Our research indicated even autoclaving at $121^{\circ} \mathrm{C}$ for 15 minutes, the standard procedure for lab scale sterilization, is an effective pretreatment method for the utilization of EFB for xylitol production (Mardawati et al., 2014).

\section{Enzymatic Hydrolysis of EFB}

Hydrolysis is the breaking down of a polymeric compound into its monomer with the addition of water molecules. The hydrolysis of EFB can be performed chemically or enzymatically. The chemical hydrolysis uses either acid or alkaline as the catalyst at high temperature and pressure (Sun \& Chen, 2002). This process is relatively fast, and thus need to be carefully controlled to prevent the co-production of various degradative products that inhibit the latter processes. Nonetheless, the process condition requires a specific material for the construction of the reactor and the related equipment. Further, subsequent $\mathrm{pH}$ neutralization is required. (Rahman et al., 2007), for example, reported the application of acid hydrolysis in the processing of oil palm EFB to xylose using dilute (2-6\%) sulfuric acid at moderate temperature, $120^{\circ} \mathrm{C}$ (Parajo et al., 1998a). The reaction should be executed within a short time such that the possible inhibitory compounds for the following xylitol fermentation, that is furfural and acetic acid, are not co-produced during the acid hydrolysis. The hydrolysis of EFB can also be performed enzymatically using lignocellulolytic enzyme (Parajo et al., 1998b). In particular, the hydrolysis of hemicellulose is catalysed by xylanolytic enzyme or in short, xylanase. Albeit proceeding slowly, the enzymatic hydrolysis works at milder condition and reacts specifically. Thereby the related utility cost for the hydrolysis process is relatively low and cheaper material can be used for the reactor and equipments. This process can be easily integrated with the fermentation (Vazques et al., 2001). The xylanase is actually an enzyme complex that has the activity to hydrolyze hemicellulose. (Shallom et al., 2003)described that this enzyme comprises of many activities, among others are 1,4- $\beta$-endoxylanase (EC.3.2.1.8), that breaks the $\beta-1,4$ glycosidic bond at the xylan main chain of the hemicellulose, and 1,4- $\beta$-exoxylosidase (EC.3.2.1.37), that breaks the $\beta-1,4$ glycosidic bond at two or four monomer from the free end of xylan .

\subsection{Availability of Xylanase}

The xylanases are found in various bacteria and fungi (Table 2). Wheat bran, corn cobs, rice bran, cassava, maize straw, and sugarcane bagasse are mostly used as sources for hemicellulose.

In our research we studied the production of xylanase from EFB in solid state fungal cultivation using A.niger ITB L.51, Tricoderma viride ITB L.67 and Penicillium sp ITB L.96. The best activity was obtained from the T.viride cultivated at $32.8{ }^{\circ} \mathrm{C}$ for 36 hours and gave the specific xylanase activity of $5,180 \mathrm{U} / \mathrm{g}$ dry substrate (Mardawati et al., 2013). The production of xylanase from EFB in solid state fungal cultivation was also reported by (Lakshmi et al., 2011) using A.tereus and A.fumigatus. Optimization of cultivation condition, such as EFB particle size, moisture content, $\mathrm{pH}$, media composition, inoculum concentration, and additional carbon source may increase the produced enzyme activity up to $40,000 \mathrm{U} / \mathrm{g}$ dry substrate. Commercial xylanase for the hydrolysis of lignocellulosic material is available in the market. Among others are produced by Novozyme (Denmark), Genecor (Mardawati et al., 2014) and Meiji Seika (Japan). The application of xylanase can also be found in biobleaching process in the pulp and paper industries, in clarification of fruit juice, quality improvement of bread and feed, waste treatment, and composting. 
Table 2. Potential Xylanase Producers

\begin{tabular}{ll}
\hline \multicolumn{1}{c}{ Microorganism } & \multicolumn{1}{c}{ Reference } \\
\hline Streptomyces $s p$ & Meryandini et al., 2008 \\
Bacillus sp & Shallom and Shoham, 2003 \\
Aspergillus $s p$ & Xu et al., 2008; Lakshmi et al., 2011 and Pal et al., 2011 \\
Penicillium & Tran et al., 2004; Knob et al., 2009 and Assamoi et al., 2008 \\
Trichoderma & Kar et al., 2008; Chen at al., 2010 and Zhou et al., 2011 \\
\hline
\end{tabular}

\subsection{Operation Condition of Hydrolysis}

Depending on the molecular structure and composition, each enzyme has a particular condition (e.g. temperature and $\mathrm{pH}$ ) whereby its activity is optimum. The optimal conditions of xylanase, for example in hydrolyzing corncob, were reported to be in the range of $45-60^{\circ} \mathrm{C}$ and $\mathrm{pH}$ of $4-5$ (Vasquez et al., 2001). The optimal condition of commercial xylanase in hydrolyzing oil palm EFB was reported at $60^{\circ} \mathrm{C}$ and $\mathrm{pH} 5.0$ (Mardawati et al., 2014).

\subsection{Kinetics of Enzymatic Hydrolysis}

The Michaelis Menten kinetics is mostly used to model enzymatic reactions. In particular, when enzyme, substrates, and products are homogeneously mixed in the aqueous solution. In the Michaelis Menten equation, the rate of enzymatic reactions (v) is described as a saturation curve of substrate concentration (S) as is described in eq. 1.

$$
v=v_{m}[S] /\left(K_{m}+[S]\right)
$$

The two kinetic parameters, vm and $\mathrm{Km}$, respectively described the maximum rate of the enzymatic reaction at a defined enzyme concentration and the enzyme affinity to the substrate. However, EFB as the substrate of enzymatic hydrolysis is insoluble solid particles and thereby the Michaelis Menten kinetics may not be applicable in describing the EFB hydrolysis reaction kinetics. (Mardawati et al., 2014) showed that at low solid loading, i.e. the ratio of EFB to the buffered enzyme solution, the hydrolysis reaction could be well approached with the Michaelis Menten kinetics (Mardawati et al., 2014). At the optimum condition, temperature of $60{ }^{\circ} \mathrm{C}$ and $\mathrm{pH} 5.0$, the kinetics parameters were estimated to be $\mathrm{v}_{\mathrm{m}}=0.34 \mathrm{~g}$ xylan. $\mathrm{L}^{-1} \cdot \mathrm{min}^{-1}$ and $\mathrm{Km}=52.84 \mathrm{~g}$ xylan. $\mathrm{L}^{-1}$. Further experiments need to be done to confirm whether this is also valid at high solid loading. Intuitively, the transport of enzyme to the substrate may be limiting. The obtained kinetics parameters can be further used to simulate and design the reaction, such as how long the hydrolysis needs to be undertaken to achieve the targeted yield. Using the above parameters, for example, xylose yield of $90 \%$ will be achieved at 6 hours of enzymatic hydrolysis of EFB with 5\% solid loading.

\section{Fermentation}

The reduction of xylose to xylitol can be performed chemically or biologically. The chemical reduction is carried out by contacting liquid xylose with pure hydrogen gas using noble metalbased catalysts such as platinum, palladium, ruthenium, or nickel, at high pressure and temperature (Baudel et al., 2005). The biological reduction of xylose is carried out by fermentation, mainly using yeast (Parajo et al., 1998b). This process is carried out at ambient temperature, pressure, and $\mathrm{pH}$. The study of microbial production of xylitol was dated back to 1969 , in search of potential yeast for converting glucose to xylitol (Onishi \& Suzuki, 1969). No direct mechanism was found to convert glucose to xylitol. Instead, glucose needs to be converted to arabitol, arabitol to xylulose, and finally xylulose to xylitol. Later studies suggested the use of xylose as the substrate for xylitol fermentation. (Parajó et al., 1998) listed several potential microorganisms for xylitol production from xylose. Among them are Candida utilis, C. tropicalis, C. guilliermondi, C. mogii, Debaromyces hansenii, Pachysolen tannophilus, and Pichia stipitis. In using xylose as the substrate, these microorganisms transport xylose from the media to the cell and converting the intracellular xylose into xylitol by xylose reductase (EC.1.1.1.21) using either NADH or NADPH as the co-enzyme. The produced xylitol further oxidized by xylitol dehydrogenase (EC.1.1.1.B19) to xylulose ((Parajo et al., 1998b). The latter can be activated by xylulose kinase into xylulose-5-phosphate that can assimilate with the Pentose Phosphate Pathway of the yeast metabolism. Some part of xylitol is transported back to the media (Ghindea et al., 2010).

How much xylitol is used in the metabolism and how much xylitol is exported as product? This will be affected among others by the amount of xylose in the substrate, the presence of co - substrate, and aeration condition as is summarised in Table 3. 
Table 3. Factors Affecting Xylitol Production in Yeast

\begin{tabular}{llc}
\hline Factors & \multicolumn{1}{c}{ Influence of factors } & \multicolumn{1}{c}{ Reference } \\
\hline Substrate concentration & $\begin{array}{l}\text { High xylose concentration led to slow xylitol } \\
\text { production due to substrate inhibition. }\end{array}$ & Parajo et al., 1998b \\
$\begin{array}{l}\text { The presence of } \\
\text { cosubstrate }\end{array}$ & $\begin{array}{l}\text { Glucose concentration (in small amount) } \\
\text { led to higher xylitol productivity due to } \\
\text { higher biomass growth. }\end{array}$ & Ghindea et al., 2010 \\
Aeration condition & $\begin{array}{l}\text { High oxygen concentration (aerobic) led } \\
\text { to higher biomass growth and low xylitol } \\
\text { production } \\
\text { Higher initial cell concentration led to } \\
\text { higher xylitol production }\end{array}$ & Barbosa et al., 1994 \\
Innoculum condition & Kresnowati et al., 2012 \\
\hline
\end{tabular}

In previous study D.hansenii ITBCC R85 can be used to produce xylitol from EFB hydrolysate (Kresnowati et al., 2012). Interestingly, the results also show higher xylitol yield, and higher products selectivity in fermentation using EFB hydrolysate compared to using synthetic media. The kinetics of xylitol production is being studied further. Further important factor is the fermentation configuration, such whether the fermentation will be performed in batch, fed batch, or continuous; whether cell will be immobilized and how.

\section{Downstream Processing}

Not many literatures are found on the topics of downstream processing of xylitol from the fermentation broth. Overall the important considerations in downstream processing of microbial production of xylitol are the characteristics of xylitol as well as other substances found in the fermentation broths. (Kresnowati et al., 2012; Kresnowati et al., 2013) observed that besides xylitol and biomass, ethanol, acetic acid, and glycerol were also produced during the xylitol fermentation. When EFB hydrolysate is used, EFB residue may also be found in the fermentation broth. Main methods used in the downstream processing of xylitol is crystallization, however, considering its composition, direct crystallization of the fermentation broth yields xylitol crystal of low quality (Aliakbarian et al., 2012). Therefore, preceding separation process is necessary. There are applied charcoal adsorption and crystallization as the downstream processing of xylitol fermentation (Sampaio et al., 2006), applied silica gel adsorption and crystallization (Musatto et al., 2006), proposed extraction, precipitation, or vacuum concentration as the preceding steps (Misra et al., 2011), proposed membrane processes that are ultrafiltration and reverse osmosis, as the preceding steps for crystallization (Affleck et al., 2000). Specific downstream processing configuration of xylitol from EFB hydrolysate has not been reported. Some proposed downstream processing configurations are presented in Figure 3.

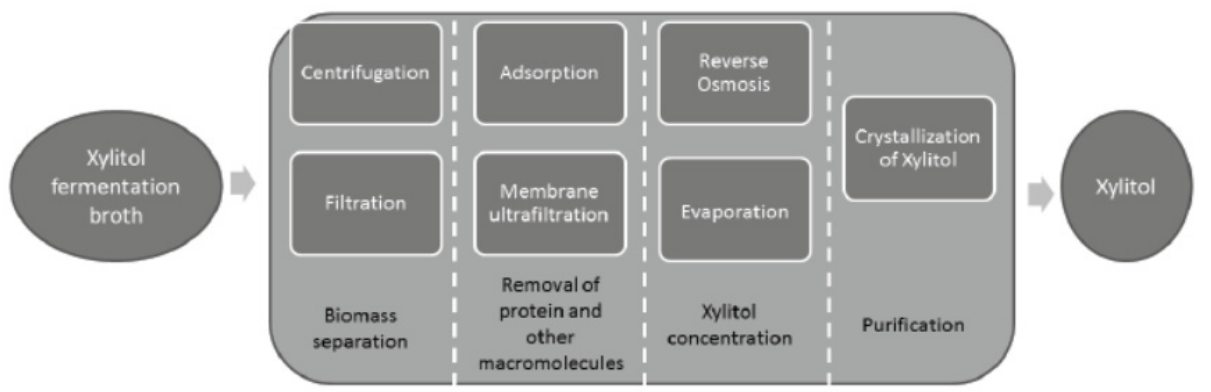

Figure 3. Alternative Process Configurations for the Downstream Processing of Microbial Xylitol Production for EFB

\section{Economic Aspect}

The economic potential of xylitol production is quite promising. For average xylitol price of $4.5 \mathrm{US} \$ \mathrm{~kg}$ (Toyoda et al., 2009), average EFB price of $150 \mathrm{IDR} / \mathrm{kg}$, and realistic yields of hydrolysate $(80 \%)$ and fermentation yield (50\%), a gross profit of 4.3 US $\$ / \mathrm{kg}$ is obtained. Even six folds increase in the EFB price or $20 \%$ decrease in the xylitol price still gives a gross profit of $3.5 \mathrm{US} \$ / \mathrm{kg}$. This value gives some flexibility in the processing cost. Still, the main process in the downstream processing of xylitol, crystallization, is an energy intensive process. Process improvement and optimization will be an advantage. Further, in considering the industrial scale, the EFB transportation and average scale oil palm industries need to be taken into consideration. 


\section{Conclusions and Future Recomendation}

This paper shows that oil palm EFB has the potential to be converted into xylitol. The process involves pretreatment, hydrolysis, fermentation, and downstream separation. Moderate temperature and pressure thermal process such as autoclave sterilization can effectively be applied as the EFB pretreatment process. Enzymatic hydrolysis followed by microbial fermentation is a more sustainable process alternative. Detail information on these processes, such as suitable microorganism and enzyme, optimal condition, and reaction kinetics, has been investigated. Process improvement and optimization are being studied. More efforts should be spent on the optimization of energy intensive downstream separation to bring this concept closer to the implementation.

\section{Acknowledgments}

This research was funded by Directorate of Higher Education, Indonesian Ministry of National Education (DIKTI) under the scheme of National Strategic Research Scheme "The Production of 'Green' Xylitol: Integrated Convertion of Biomass Waste of Palm Oil into Bioethanol and Valuable Chemicals".

\section{References}

Affleck, R. (2000). Recovery of xylitol from fermentation of model hydrolysate using membrane technology, State University of Virginia, Master of Science.

Aliakbarian, B., d Faveri, D., Perego, P., \& Converti, A. (2012). An Assessment on Xylitol Recovery Methods. in S. S. d. Silva and A. K. Chandel. D-Xylitol: Fermentative Production. Application and Commercialization, Springer Verlag. http://dx.doi.org/10.1007/978-3-642-31887-0_10

Assamoi, A., Destain, J., Delvigne, F., Lognay, G., \& Thonart, P. (2008). Solid-State Fermentation of Xylanase from Penicilliumcanescens 10-10c in a Multi-Layer-Packed Bed Reactor. Applied Biochemical and Biotechnology, 145(1-3), 87-98. http://dx.doi.org/10.1007/s12010-007-8077-z

Barbosa, M., Medeiros, M. I., \& Mancilha, B. A. (1994). Biochemistry and physiology of xylose for production of xylitol from D-xylose and some factors which affect xylitol yield in Candida guilliermondii. J. Ind. Microbiol, 3, 241-251. http://dx.doi.org/10.1007/BF01569582

Baudel, H., Abreu, C., \& Zaror, C. (2005). Xylitol production via catalytic hydrogenation of sugarcane bagasse dissolving pulp liquid effluents over Ru/C catalyst. Journal of Chemical Technology \& Biotechnology, 80(2), 230-233. http://dx.doi.org/10.1002/jctb.1155

Chang, S. H. (2014). An overview of empty fruit bunch from oil palm as feedstock for bio-oil production. Biomass and Bioenergy, 62, 174-181. http://dx.doi.org/10.1016/j.biombioe.2014.01.002

Chen, X., Xingzho, X., \& Shunqing, Z. (2010). Site-directed mutagenesis of an Aspergillus niger xylanase B and its expression, purification and enzymatic characterization in Pichia pastoris. Process Biochemistry, 45(1), 75-80. http://dx.doi.org/10.1016/j.procbio.2009.08.009

Choi, W., Park, J., Lee, J., Oh, Y., Park, Y., Kim, J., Park, J., Kim, C., \& Lee, J. (2013). Optimization of $\mathrm{NaOH}$-catalyzed steam pretreatment of empty fruit bunch. Biotechnol Biofuels, 6(1). http://dx.doi.org/10.1186/1754-6834-6-170

Embrandiri, A., Singh, R. P., Ibrahim, H. M., \& Ramli, A. A. (2012). Land application of biomass residue generated from palm oil processing: Its potential benefits and threats. Environmentalist, 32(1), 111-117. http://dx.doi.org/10.1007/s10669-011-9367-0

Ghindea, R., \& Csutak, O. (2010). Production of Xilitol by Yeast. Romanian Biotechnological Letters, 15(3).

Hassan, M. A., Yee, L. N., Yee, P. L., Ariffin, H., Raha, A. R., Shirai, Y., \& Sudesh, K. (2013). Sustainable production of polyhydroxyalkanoates from renewable oil-palm biomass. Biomass and Bioenergy, 50, 1-9. http://dx.doi.org/10.1016/j.biombioe.2012.10.014

Imman, S., Arnthong, J., Burapatana, V., Laosiripojana, N., \& Champreda, V. (2013). Autohydrolysis of tropical agricultural residues by compressed liquid hot water pretreatment. Appl Biochem Biotechnol, 170(8), 1982-1995. http://dx.doi.org/10.1007/s12010-013-0320-1

Isroi, M. Ishola, Millati, R., Syamsiah, S., Cahyanto, M., Niklasson, C., \& Taherzadeh, M. (2012). Structural changes of oil palm empty fruit bunch (OPEFB) after fungal and phosphoric acid pretreatment. Molecules, 17(12), 14995-15002. http://dx.doi.org/10.3390/molecules171214995

Kar, S., Mandal, A., Mohapatra, P., Samanta, S., Pati, B., \& Mondal, K. (2008). Production of xylanase by immobilized Trichoderma reesei SAF3 in Ca-alginate beads. Ind Microbiol Biotechnol, 35, 245-249. 
http://dx.doi.org/10.1007/s10295-007-0292-7

Kim, J., Choi, W., Kang, M., Park, J., \& Lee, J. (2012). Kinetic study of empty fruit bunch using hot liquid water and dilute acid. Appl Biochem Biotechnol, 167(6), 1527-1539. http://dx.doi.org/10.1007/s12010-011-9528-0

Knob, A., \& Eleonora, C. (2009). Cell-associated acid $\beta$-xylosidase production by Penicillium sclerotiorum. New Biotechnology, 26, 60-67. http://dx.doi.org/10.1016/j.nbt.2009.03.002

Kresnowati, M. T. A. P., Setiadi, T., Tantra, T. M., \& David (2013). Microbial Production of Xylitol from Palm Oil Empty Fruit Bunches Hydrolysate: Effects of Initial Cell Concentration and pH. International Seminar on Biorenewable Resources Utilization for Energy and Chemicals, Bandung, Indonesia.

Kresnowati, M., Ardina, A. B., \& Oetomo, V. P. (2012). From Palm Oil Waste to Valuable Products: Microbial Production of Xylitol 19th Regional Symposium of Chemical Engineering, Bali, Indonesia.

Lakshmi, G., Suvarna, G., \& Prakasham, P. (2011). Sustainable Bioprocess Evaluation for Xylanase Production by Isolated Aspergillus terreus and Aspergillus fumigatus Under Solid - State Fermentation Using Oil Palm Empty Fruit Bunch Fiber. Current Trends in Biotechnology \& Pharmacy, 5(4), 1434-1444.

Mahjoub, R., Bin Mohamad Yatim, J., \& Mohd Sam. A. R. (2013). A review of structural performance of oil palm empty fruit bunch fiber in polymer composites. Advances in Materials Science and Engineering. http://dx.doi.org/10.1155/2013/415359

Mardawati, E., Werner, A., Bley, T., Kresnowati, M., \& Setiadi, T. (2014). The Enzymatic Hydrolysis of Oil Palm Empty Fruit Bunches to Xylose. Journal of Japan Institute of Energy, 93, 973-978. http://dx.doi.org/10.3775/jie.93.973

Mardawati, E., Stephanie, Arlene, Kresnowati, M., \& Setiadi, T. (2013). Optimization of Xylanase Production From Palm Oil Empty Fruit Bunches. International Seminar on Biorenewable Resources Utilization for Energy and Chemicals 2013 Bandung, Indonesia.

Meryandini, A., Widhyastuti, N., \& Lestari, Y. (2008). Pemurnian dan Karakterisasi xilanase Streptomyces sp. SKKI-8. Jurnal Makara Sains, 12(2), 55-60.

Millati, R., Wikandari, R., Trihandayani, E., Cahyanto, M., Taherzadeh, M., \& Niklasson, C. (2011). Ethanol from Oil Palm Empty Fruit Bunch via Dilute-Acid Hydrolysis and Fermentation by Mucor indicus and Saccharomyces cerevisiae. Agricultural Journal, 6, 54-59. http://dx.doi.org/10.3923/aj.2011.54.59

Misra, S., Pritesh, G., Shailendra, R., Kakoli, D., \& Saxena, R. (2011). Comparative study on different strategies involved for xylitol purification from culture media fermented by Candida tropicalis. Sep Purif Technol, 78, 266-273. http://dx.doi.org/10.1016/j.seppur.2011.02.018

Mosier, N., Wyman, C., Dale, B., Elander, R., Lee, Y., Holtzapple, M., \& Ladisch, M. (2005). Features of Promising Technologies for Pretreatment of Lignocellulosic Biomass. Bioresource Technology, 96, 673-686. http://dx.doi.org/10.1016/j.biortech.2004.06.025

Musatto, S. I., Silva, C., \& Roberto, I. C. (2006). Fermentation performance of Candida guilliermondii for xylitol production on single and mixed substrate media. Appl Microbiol Biotechnol, 72, 681-686. http://dx.doi.org/10.1007/s00253-006-0372-z

Octavia, S. (2013). Pengolahan Awal Berbasis Amonia Terhadap Biomassa Lignoselulosa Bahan Mentah Pembuatan Bioetanol Chemical Engineering. Bandung, Indonesia, Institut Teknologi Bandung. Doctoral dissertation.

Onishi, H., \& Suzuki, T. (1969). Microbial production of xylitol from glucose. Applied microbiology, 18(6), 1031-1035.

Pal, A., \& Khanum, F. (2011). Purification of xylanase from Aspergillus niger DFR-5: Individual and interactive effect of temperature and $\mathrm{pH}$ on its stability. Process Biochemistry, 46, 879-887. http://dx.doi.org/10.1016/j.procbio.2010.12.009

Parajó, J. C., Domínguez, H., \& Domínguez, J. M. (1998a). Biotechnological production of xylitol. Part 1: Interest of xylitol and fundamentals of its biosynthesis. Bioresource Technology, 65(3), 191-201. http://dx.doi.org/10.1016/S0960-8524(98)00038-8

Parajó, J. C., Domínguez, H., \& Domínguez, J. M. (1998b). Biotechnological production of xylitol. Part 2: Operation in culture media made with commercial sugars. Bioresource Technology, 65(3), 203-212. http://dx.doi.org/10.1016/S0960-8524(98)00036-4 
Rahman, S. H. A., Choudhury, J. P., Ahmad, A. L., \& Kamaruddin, A. H. (2007). Optimization studies on acid hydrolysis of oil palm empty fruit bunch fiber for production of xylose. Bioresource Technology, 98(3), 554-559. http://dx.doi.org/10.1016/j.biortech.2006.02.016

Rupani, P. F. R., Singh, P., Ibrahim, M. H., \& Esa, N. (2010). Review of Current Palm Oil Mill Effluent (POME) Treatment Methods: Vermicomposting as a Sustainable Practice. World Applied Sciences Journal, 11(1), $70-81$.

Sampaio, F., Passos, F. L., Passos, F. V., Faveri, D. d., Perego, P., \& Converti, A. (2006). Xylitol crystallization from culture media fermented by yeasts. Chem Eng Process, 45, 1041-1046. http://dx.doi.org/10.1016/j.cep.2006.03.012

Shallom, D. Y. (2003). Shoham. Microbial hemicellulases. Current Opinion in Microbiology, 6, 219-228. http://dx.doi.org/10.1016/S1369-5274(03)00056-0

Singh, P., Sulaiman, O., Hashim, R., Peng, L. C., \& Singh., R. P. (2013). Using biomass residues from oil palm industry as a raw material for pulp and paper industry: Potential benefits and threat to the environment. $\begin{array}{llll}\text { Environment, Development and } & \text { 367-383. }\end{array}$ http://dx.doi.org/10.1007/s10668-012-9390-4

Sudiyani, Y., Styarini, D., Triwahyuni, E., Sudiyarmanto, Sembiring, K. C., Aristiawan, Y., Abimanyu, H., \& Han., M. H. (2013). Utilization of Biomass Waste Empty Fruit Bunch Fiber of Palm Oil for Bioethanol Production Using Pilot-Scale Unit. Energy Procedia, 32(0), 31-38. http://dx.doi.org/10.1016/j.egypro.2013.05.005

Sun, Y., \& Cheng, J. (2002). Hydrolysis of lignocellulosic materials for ethanol production: a review. Bioresource Technology, 83(1), 1-11. http://dx.doi.org/10.1016/S0960-8524(01)00212-7

Susanto, H., \& Budhi, Y. W. (1997). Pemanfaatan Tandan Kosong Sawit sebagai Sumber Energi Alternatif Melalui Proses Gasifikasi. Pertemuan Teknis Kelapa Sawit, Medan.

Tan, L., Yu, Y., Li, X., Zhao, J., Qu, Y., Choo, Y., \& Loh., S. (2013). Pretreatment of empty fruit bunch from oil palm for fuel ethanol production and proposed biorefinery process. Bioresour Technol, 135, 275-282. http://dx.doi.org/10.1016/j.biortech.2012.10.134

Toyoda, T., \& Ohtaguchi, K. (2009). Xylitol Production from Lactose by Biotransformation. Journal Biochemical Technology, 2(1), 126-132.

Tran, L., Yogo, M., Ojima, H., Idota, O., Kawai, K., Suzuki, T., \& Takamizawa, K. (2004). The Production of Xylitol by Enzymatic Hydrolysis of Agricultural Wastes. Biotechnology and Bioprocess Engineering, 9, 223-228. http://dx.doi.org/10.1007/BF02942297

Vázquez, M., Alonso, J., Domínguez, H., \& Parajó, J. (2001). Production of xylose-containing fermentation media by enzymatic post-hydrolysis of oligomers produced by corn cob autohydrolysis. World Journal of Microbiology and Biotechnology, 17, 817-822. http://dx.doi.org/10.1023/A:1013563628882

Visvanathan, C., Setiadi, T., Herarth, G., \& Shi, H. (2009). Eco-Industrial Clusters in Urban-Rural Fringe Areas, Asian Institute of Technology, Thailand.

Xu, Y., Li, Y., Xu, S., Wang, X., \& Tang, J. (2008). Improvement of xylanase production by Aspergillus niger $\mathrm{XY}-1$ using response surface methodology for optimizing the medium composition. Zhejiang University Science, 9(7), 558-566. http://dx.doi.org/10.1631/jzus.B0820038

Zainudin, M. H. M., Hassan, U. K., Md Shah, N., Abdullah, M., Tokura, H., Yasueda, Y., Shirai, K., \& Sakai, A. S. (2014). Baharuddin. Bacterial community structure and biochemical changes associated with composting of lignocellulosic oil palm empty fruit bunch. BioResources, 9(1), 316-335.

Zhou, P., Zhu, H., Yan, Q., Katrolia, P., \& Jiang, Z. (2011). Purification and Properties of a Psychrotrophic Trichoderma sp. Xylanase and its Gene Sequence. Appl Biochem Biotechnol, 164, 944-956. http://dx.doi.org/10.1007/s12010-011-9186-2

\section{Copyrights}

Copyright for this article is retained by the author(s), with first publication rights granted to the journal.

This is an open-access article distributed under the terms and conditions of the Creative Commons Attribution license (http://creativecommons.org/licenses/by/3.0/). 